\title{
Ewolucja systemowego leczenia przeciwnowotworowego
}

\author{
Maciej Krzakowski
}

Postępowanie dostosowane do charakterystyki klinicznej i molekularnej chorych stanowi najbardziej obiecujący kierunek rozwoju możliwości systemowego leczenia przeciwnowotworowego. Ostatnie obserwacje wykazują, że istotny postęp w zakresie możliwości systemowego leczenia może być związany również z wykorzystaniem metod oddziaływania na układ immunologiczny chorych. Ważne jest również postępowanie wielospecjalistyczne, co oznacza kojarzenie różnych metod farmakoterapii oraz metod leczenia miejscowego i systemowego. Celem obecnego artykułu jest przedstawienie i omówienie najważniejszych kierunków rozwoju systemowego leczenia przeciwnowotworowego.

\section{Evolution of systemic anti-cancer treatment}

Tailored to clinical and molecular characteristics of a patient's management is the most promising direction in the evolution of systemic anti-cancer treatment. Recent observations show, that significant progress may be also related to the use of methods addressing the immune system of patients. The use of multidisciplinary management is important since, that represents combined administration of various pharmacological treatments as well as the use of loco-regional and systemic methods. The aim of this paper is to discuss the most important ways in the evolution of systemic anti-cancer treatment.

NOWOTWORY Journal of Oncology 2015; 65, 1: 1-6

Słowa kluczowe: systemowe leczenie przeciwnowotworowe, ewolucja możliwości leczenia, nowotwory złośliwe Key words: systemie anticancer treatment, evolution of therapeutic options, malignant neoplasms

\section{Wprowadzenie}

Wyniki przeciwnowotworowego leczenia zależą od czynników związanych z charakterystyką nowotworu (np. typ i stopień histologicznej złośliwości, stopień zaawansowania oraz charakterystyka genetyczna i molekularna), cechami chorego (stan sprawności, wiek, współwystępujące choroby) oraz czynnikami związanymi z zastosowanym postępowaniem diagnostyczno-terapeutycznym. Lepsze rokowanie chorych może wynikać z odpowiednio wczesnego wykrywania oraz prawidłowego ustalania rozpoznania i zaawansowania nowotworu, stosowania właściwego leczenia ustalanego w ramach wielospecjalistycznych zespołów, z uwzględnieniem znaczenia czynników prognostycznych i predykcyjnych oraz indywidualnych uwarunkowań medycznych i społecznych, bieżącego monitorowania przebiegu leczenia i dostosowania postępowania do bieżącej sytuacji (w tym — podejmowanie właściwego leczenia wspomagającego w sytuacji wystąpienia powikłań) oraz starannego obserwowania chorych po leczeniu.

Systemowe leczenie - stosowanie leków o działaniu cytotoksycznym i hormonalnym oraz dostosowanych do genetycznej charakterystyki nowotworów lub wykorzystujących mechanizmy immunologiczne - jest jedną z trzech podstawowych metod przeciwnowotworowego postępowania. Systemowe leczenie prowadzi do uzyskania wyleczenia w nielicznych nowotworach w przypadku wyłącznego stosowania, ale odgrywa bardzo ważną rolę w radykalnym postępowaniu w przypadku kojarzenia z metodami o działaniu miejscowym. Znaczenie systemowego leczenia staje się w ostatnich latach coraz większe w związku z poznaniem genomu i ewolucją rozumienia molekularnych uwarunkowań wielu nowotworów [1, 2]. 
Najważniejszymi kierunkami rozwoju systemowego leczenia wydaje się właściwe wykorzystanie biologicznych czynników o wartości predykcyjnej, stosowanie leczenia ukierunkowanego na cele molekularne i oddziaływanie na mechanizmy immunologiczne oraz kojarzenie metod. Bardzo istotne są zmiany wzorców podejścia w poszczególnych sytuacjach klinicznych.

\section{Predykcyjne czynniki dla leków ukierunkowanych na cele molekularne}

Indywidualizacja postępowania polega przede wszystkim na dostosowaniu metod leczenia do charakterystyki poszczególnych chorych, z wykorzystaniem cech demograficznych i klinicznych oraz genetycznych i molekularnych.

Archetypem leczenia ukierunkowanego na cele molekularne (tzw. leczenia celowanego) jest hormonoterapia w raku piersi. Poznanie znaczenia mechanizmów hormonozależności raka piersi doprowadziło do wprowadzenia leczenia, które obecnie jest stosowane u około $70 \%$ chorych i prowadzi do uzyskania znaczących korzyści przy niewielkim ryzyku wystąpienia poważnych działań niepożądanych. Uzupełnienie wiedzy na temat biologii raka piersi o znaczenie stanu HER2 było podstawą wprowadzenia pierwszego leku ukierunkowanego nowej generacji, jakim jest trastuzumab (monoklonalne przeciwciało anty-HER2) [3]. Wykorzystanie oceny stanu steroidowych receptorów hormonalnych i białka HER2 lub/i genu HER2 oraz wskaźnika proliferacji komórkowej jest podstawą nowoczesnej klasyfikacji immunohistochemicznej raka piersi, która wyróżnia 5 typów o różnym rokowaniu i wymagających odmiennego leczenia. W związku z poznaniem różnic molekularnych raka piersi wprowadzono do praktyki klinicznej kilka następnych leków ukierunkowanych, których stosowanie może przyczyniać się do poprawy wyników leczenia. Poznanie struktury genomu ma już obecnie coraz większe znaczenie dla tradycyjnych metod systemowego leczenia, czego przykładem są próby dostosowania rodzaju hormonoterapii do charakterystyki genetycznej nowotworu [4].

Kolejnym przykładem nowotworu, w którym poznanie charakterystyki molekularnej znajduje odbicie w szerszym spektrum możliwości leczenia, jest gruczołowy rak płuca. Wieloletnie badania wielu grup doprowadziły do określenia ponad połowy zaburzeń genetycznych i molekularnych w raku gruczołowym płuca, z których największe znaczenie praktyczne ma obecność aktywujących mutacji w genie EGFR (10-12\% chorych rasy kaukaskiej) i rearanżacji genu ALK (5\% chorych). Obecność wspomnianych zaburzeń jest czynnikiem predykcyjnym korzyści możliwych do uzyskania w wyniku stosowania inhibitorów tyrozynowej kinazy [5]. Potwierdzeniem wartości związanych ze stosowaniem wymienionych leków, które polegają na znamiennym wydłużeniu czasu przeżycia wolnego od progresji choroby i znacznie lepszej tolerancji w porównaniu z chemioterapią, są wyniki wielu badań z losowym doborem chorych oraz metaanalizy [6].

Podobne znaczenie ma identyfikacja znaczenia stanu genów RAS w raku jelita grubego - prawidłowy stan genów KRAS i NRAS występuje u około $50 \%$ chorych i jest czynnikiem predykcyjnym korzyści związanych z zastosowaniem monoklonalnych przeciwciał anty-EGFR (panitumumab i cetuksymab - stosowane w skojarzeniu z chemioterapią lub samodzielnie). W porównaniu z wyłącznym stosowaniem leków cytotoksycznych leczenie pierwszej linii z udziałem monoklonalnych przeciwciał i chemioterapii prowadzi u chorych na zaawansowanego raka jelita grubego do znamiennego wydłużenia czasu przeżycia całkowitego, którego mediana - w przypadku doboru chorych na podstawie stanu genów RAS — wynosi obecnie około trzech lat [7].

Warunkiem sukcesu osiąganego w związku ze stosowaniem leków ukierunkowanych na cele molekularne jest prawidłowość wykrywania zaburzeń — biomarkery powinny być oceniane z wykorzystaniem testów o potwierdzonej wartości, w laboratoriach zapewniających wiarygodne wyniki dostarczane w odpowiednio krótkim czasie. Laboratoria biologii molekularnej — działające w ścisłej współpracy z pracowniami patomorfologii — powinny otrzymywać certyfikaty w toku zewnętrznej walidacji i muszą być bezwzględnie poddawane okresowej kontroli jakości [8].

Istotne znaczenie ma zrozumienie złożoności zaburzeń genetycznych i molekularnych w nowotworach. Wspomniana złożoność polega - między innymi - na występowaniu licznych zaburzeń, które mogą występować w różnym stopniu nasilenia w poszczególnych częściach nowotworu. Złożoność omawianych zaburzeń wskazuje na konieczność zmiany podejścia diagnostycznego w biologii molekularnej i odstąpienia od wykonywania wielu testów w celu wykrywania pojedynczych mutacji na rzecz wprowadzania metod „,wielogenowej” oceny [9]. Konieczne jest jednocześnie opracowanie metod oceny charakterystyki genetycznej i molekularnej w badaniach nie tylko tzw.,świeżego" materiału tkankowego, ale również formalinowych preparatów umieszczonych w parafinie lub nowotworowych komórek znajdujących się we krwi [10].

Znaczenie molekularnej złożoności nowotworów udowadnia sytuacja, która dotyczy chorych na mięsaka podścieliskowego przewodu pokarmowego oraz niedrobnokomórkowego raka płuca.

Nowotwory podścieliskowe przewodu pokarmowego stanowią — pod względem molekularnym — złożoną grupę chorób. U większości chorych (około 85\%) występują aktywujące - wzajemnie wykluczające się — mutacje w genach KIT i PDGFRA, których obecność ma znaczenie predykcyjne dla leków z grupy inhibitorów kinaz tyrozynowych [11]. Większość (niemal 70\%) mutacji w genie KIT występuje w eksonie 11., ale u niewielkiej grupy chorych zaburzenia dotyczą innych eksonów (np. 9., 13. i 17.). Różnice dotyczą 
Tabela I. Predykcyjne znaczenie rodzaju mutacji w mięsakach podścieliskowych przewodu pokarmowego

\begin{tabular}{lll}
\hline Gen & Ekson & Znaczenie predykcyjne \\
\hline KIT & 11 & odpowiedź bardzo częsta - imatynib (dobowa dawka $400 \mathrm{mg}$ ) \\
& 9 & odpowiedź częsta - imatynib (dobowa dawka $800 \mathrm{mg}$ ) oraz sunitynib \\
& $13 \mathrm{i} 17$ & odpowiedź niekiedy obserwowana - imatynib \\
\hline PDGFRA & 12 & odpowiedź niekiedy obserwowana - imatynib \\
& 18 & odpowiedź obserwowana - sunitynib (częściej niż imatynib) \\
\hline
\end{tabular}

również mutacji w genie PDGFRA.W zależności od umiejscowienia mutacji skuteczność inhibitorów wielokinazowych może się różnić (tab. I) [12], co jest już obecnie wykorzystywane w praktyce.

Zależność umiejscowienia mutacji wykazano również w przypadku skuteczności afatynibu (nieodwracalny inhibitor tyrozynowej kinazy EGFR) u chorych na gruczołowego raka płuca - analiza wyników dwóch badań z losowym doborem chorych, w których afatynib porównano z chemioterapią u chorych z obecnością mutacji w genie EGFR, wykazała znacznie lepszą skuteczność afatynibu w przypadku delecji eksonu 19. w porównaniu z substytucją eksonu 21. (mediany czasu przeżycia ogółem dla afatynibu i chemioterapii - odpowiednio w przypadku wymienionych zaburzeń - 31 w porównaniu z 21 miesiącami oraz 22 i 27 miesiącami) [13]. Wyniki analizy wymagają potwierdzenia, ale mogą sugerować znacznie mniejszą wartość leczenia anty-EGFR u chorych z mutacją EGFR polegającą na substytucji eksonu 21. wspomnianego genu.

Istnieją liczne przykłady sukcesów osiągniętych w następstwie stosowania nowych leków o działaniu skierowanym na cele molekularne. Istotne jest, że wielokrotnie sukcesy dotyczą chorych na nowotwory, w których do niedawna leczenie systemowe miało ograniczoną wartość, np. leki celowane istotnie poprawiły wskaźniki przeżycia chorych na zaawansowanego raka nerkowokomórkowego lub raka gruczołu krokowego opornego na kastrację. Jednak obserwowane są również — niezależne od teoretycznego uzasadnienia - niepowodzenia prób stosowania leków ukierunkowanych na określone cele molekularne. Przyczyny wspomnianych niepowodzeń są złożone, ale — przede wszystkim — związane są z molekularnymi różnicami występującymi u chorych z określonym rozpoznaniem patomorfologicznym, które wpływają na występowanie odmienności pod względem skuteczności i toksyczności leków. Wydaje się również, że nadal - w przypadku wielu metod ukierunkowanego leczenia - nie są znane mechanizmy oporności oraz przeciwdziałania występowaniu wspomnianego zjawiska. Przykładem niepowodzenia jest nieudana próba zastosowania leku (onartuzumab) o działaniu skierowanym na szlak przekazu sygnałów cMET u chorych na niedrobnokomórkowego raka płuca. Onartuzumab jest monoklonalnym przeciwciałem, które hamuje wiązanie receptora cMET z ligandem i blokuje aktywację szlaku przekazu sygnałów. Połączenie onartuzumabu z lekami anty-EGFR wydaje się logicznym rozwiązaniem u chorych na niedrobnokomórkowego raka płuca z mutacją w genie EGFR ze względu na możliwość bardziej kompleksowego blokowania przekazu sygnałów. Wyniki badania II fazy z randomizacją [14], w którym chorzy otrzymywali erlotynib wyłącznie lub w skojarzeniu z onartuzumabem, były jednak negatywne pod względem najważniejszego wskaźnika skuteczności, jakim było wydłużenie czasu przeżycia ogółem. Przyczyną niepowodzenia było nieuwzględnienie - podczas planowania badania - znaczenia stanu cMET i brak oczekiwanej poprawy wyników u chorych z ujemnym stanem cMET. Podczas planowania badań nowych leków należy zawsze uwzględniać złożoność molekularnych zaburzeń i dostosować zasady kwalifikowania chorych oraz liczebność próby.

\section{Immunoterapia}

Istotą przeciwnowotworowej immunoterapii jest spowodowanie immunologicznej odpowiedzi skierowanej przeciw antygenom, co może prowadzić do niszczenia komórek nowotworu. Zrozumienie kluczowej roli aktywacji limfocytów T i procesów odpowiedzialnych za zwiększenie cytotoksyczności wspomnianych komórek przyczyniło się do znaczącego rozwoju metod immunoterapii. Wspomniany rozwój dotyczy przede wszystkim nowotworów immunozależnych (np. czerniak). Coraz bardziej wartościowe wyniki są również uzyskiwane w nowotworach, w których dotychczas immunoterapia była uznawana za metodę nieskuteczną (np. niedrobnokomórkowy raka płuca).

Jednym z najważniejszych mechanizmów, które prowadzą do uzyskania większej aktywności limfocytów T, jest pobudzenie związane z zahamowaniem powierzchniowego białka CTLA-4. W wielu nowotworach (np. czerniak) obecność białka CTLA-4 blokuje rozwój odpowiedzi immunologicznej — zahamowanie białka CTLA-4 przez związanie z monoklonalnymi przeciwciałami (np. ipilimumab) może znieść negatywny mechanizm regulacji aktywności limfocytów T [15]. Korzystne wyniki stosowania ipilimumabu dotyczą leczenia pierwszej oraz drugiej linii $[16,17]$ i są — na podstawie pośrednich porównań — lepsze niż w przypadku tradycyjnych metod immunoterapii. 
Tabela II. Ewolucja możliwości immunoterapii w czerniaku — leczenie anty-PD-1 w porównaniu z interferonem i interleukiną

\begin{tabular}{lcc}
\hline Wskaźnik przeżycia & $\begin{array}{c}\text { Interferon/ } \\
\text { /Interleukina }\end{array}$ & $\begin{array}{c}\text { Przeciwciała } \\
\text { anty-PD-1 }\end{array}$ \\
\hline $\begin{array}{l}\text { Czas przeżycia ogółem } \\
\text { (mediana) }\end{array}$ & $10-12$ miesięcy & $16-18$ miesięcy \\
$\begin{array}{l}\text { Przeżycia 2-letnie } \\
\text { (odsetek) }\end{array}$ & $20-25 \%$ & $50-75 \%$ \\
\hline
\end{tabular}

Jeszcze bardziej obiecującym kierunkiem w nieswoistej immunoterapii wydaje się być wykorzystanie blokowania tzw. punktów kontrolnych układu immunologicznego (np. receptor PD-1 i ligand PD-L1), co prowadzi do stymulacji limfocytów T. Przeciwciała anty-PD-1 (np. pembrolizumab lub niwolumab) powodują obiektywne odpowiedzi u wielu chorych (około 50\%) oraz — przede wszystkim — długotrwałe korzyści pod względem przeżycia. Zastosowanie leczenia anty-PD-1 prowadzi przynajmniej do podwojenia wskaźników przeżycia chorych na zaawansowanego czerniaka w porównaniu z immunoterapią interferonem lub interleukiną z (tab. II) [18, 19].

Należy oczekiwać, że nowoczesna immunoterapia znajdzie niedługo zastosowanie w uzupełniającym leczeniu chorych na czerniaka oraz będzie mogła być wykorzystana w leczeniu chorych na inne nowotwory.

\section{Kojarzenie metod leczenia ukierunkowanego}

Poprawy wyników leczenia należy szukać w kojarzeniu metod leczenia celowanego z chemioterapią lub innymi lekami ukierunkowanymi na cele molekularne.

Jednym z przykładów jest stosowanie tzw. koniugatów zawierających monoklonalne przeciwciała i leki o działaniu cytotoksycznym. Połączenie trastuzumabu z emtanzyną (lek cytotoksyczny) umożliwia internalizację wymienionego leku do wnętrza komórek nowotworu i jego uwolnienie w lizosomach, co prowadzi do zahamowania podziału wskutek polimeryzacji układu mikrotubularnego w jądrze. Wyniki badania III fazy [20] wykazały skuteczność wspomnianego koniugatu u chorych na zaawansowanego raka piersi z dodatnim stanem HER2, u których wcześniej stwierdzono niepowodzenie leczenia trastuzumabem - w porównaniu z leczeniem lapatynibem i kapecytabiną stwierdzono znamienne wydłużenie czasu przeżycia ogółem (mediany — odpowiednio - 31 i 25 miesięcy).

Leki celowane mogą wnosić dodatkową wartość w skojarzeniu z innymi metodami ukierunkowanego leczenia - przykładem jest hamowanie szlaku m-TOR, którego wzmożona aktywność jest jednym z czynników odpowiedzialnych za oporność na trastuzumab. W badaniu III fazy BOLERO-3 [21] chore na HER2-dodatniego raka piersi w stadium zaawansowanym - opornego na leczenie trastuzumabem - otrzymywały wymieniony lek i winorelbi- nę z ewerolimusem lub bez ewerolimusu. Znamiennemu wydłużeniu czasu przeżycia wolnego od progresji choroby towarzyszyła jednak większa toksyczność leczenia z udziałem ewerolimusu (zwłaszcza - niedokrwistość, gorączka neutropeniczna i zapalenie błon śluzowych), co wskazuje na konieczność uwzględnienia zjawiska występowania częstszych powikłań podczas kojarzenia leków celowanych.

Innym przykładem korzyści uzyskiwanych w następstwie kojarzenia nowoczesnych metod leczenia systemowego jest oddziaływanie na kilka receptorów błonowych (tzw. podwójna blokada) za pomocą połączenia trastuzumabu z pertuzumabem. Dodanie pertuzumabu do trastuzumabu i docetakselu spowodowało znamienne wydłużenie czasu przeżycia ogółem chorych na zaawansowanego raka piersi $z$ dodatnim stanem HER2 w badaniu III fazy — wydłużenie wyniosło niemal 16 miesięcy (odpowiednio - 56,5 w porównaniu z 40,8 miesiąca) i nie zostało uzyskane kosztem znamiennie gorszej tolerancji leczenia [22].

Nie zawsze jednak próby kojarzenia metod (między innymi - stosowanie koniugatów) przynoszą oczekiwany wynik - w wielu przypadkach teoretyczne przesłanki nie zostały potwierdzone wynikami badań klinicznych. Przyczyny niepowodzeń mogą być różne — niedostateczne może być wiązanie koligatów z receptorami błonowymi oraz absorpcja leku do wnętrza komórek i uwalnianie w lizosomach, a także nie zawsze zastosowane leki mają odpowiednio wysoką cytotoksyczność.

\section{Zmiany wzorców postępowania}

Zmiana przyjętych paradygmatów postępowania jest niewątpliwie jedną z możliwości uzyskania poprawy wyników leczenia chorych na nowotwory. Przykładem stopniowej ewolucji w zakresie podejścia jest stosowanie podtrzymującego leczenia chorych na lite nowotwory, które — w odróżnieniu od białaczek i chłoniaków — było tradycyjnie uznawane za postępowanie o stosunkowo niewielkiej wartości z powodu braku udokumentowania korzystnego wpływu na czas przeżycia ogółem. W ostatnim czasie przedstawione zostały wyniki kilku badań, które uzasadniają stosowanie przedłużonego - podtrzymującego - leczenia po uzyskaniu odpowiedzi na indukującą chemioterapię.

Badanie III fazy PARAMOUNT [23] — przeprowadzone u chorych na niepłaskonabłonkowego raka płuca w stadium zaawansowanym - wykazało, że zastosowanie monoterapii pemetreksedem po uzyskaniu odpowiedzi lub stabilizacji w następstwie indukującego leczenia cisplatyną i pemetreksedem (4 cykle) wpłynęło na ogólny czas przeżycia. Czas przeżycia ogółem był znamiennie dłuższy ( 14 w porównaniu z 11 miesiącami) u chorych otrzymujących podtrzymujące leczenie pemetreksedem w porównaniu z chorymi otrzymującymi placebo.

Korzyści w następstwie podtrzymującego leczenia odnotowano również w raku piersi (kapecytabina z bewacyzu- 
mabem w porównaniu z bewacyzumabem) [24] i mięsakach tkanek miękkich (trabektedyna w porównaniu z obserwacją) [25], ale znamienne korzyści dotyczyły jedynie czasu przeżycia wolnego od progresji choroby.

Podtrzymujące leczenie jest nadal metodą postępowania, której wykorzystanie w praktyce klinicznej jest związane z wieloma kontrowersjami. W związku z dłuższym stosowaniem skróceniu ulega tzw. czas przeżycia wolnego od leczenia, co w przypadku paliatywnego postępowania ma istotne znaczenie (szczególnie wobec nieuniknionego wystąpienia niepożądanych działań). Największym wyzwaniem jest określenie wartościowych czynników o znaczeniu predykcyjnym, ponieważ dotychczasowe cechy kliniczne nie zapewniają optymalnego wykorzystania podtrzymującego leczenia. Wartościowymi czynnikami mogą być — w przypadku leczenia podtrzymującego — biomarkery. Niemniej jednak wykazanie możliwości wydłużenia czasu przeżycia wskazuje na konieczność zmiany podejścia.

W kilku nowotworach leczenie chorych z przerzutami w wątrobie polega - przynajmniej w części przypadków - na wykorzystaniu resekcji w skojarzeniu z chemioterapią. Z drugiej strony w niektórych nowotworach u chorych z przerzutami w wątrobie stosowano w klinicznej praktyce wyłącznie leczenie systemowe - przykładem jest czerniak (szczególnie wobec znacznego poszerzenia możliwości leczenia). Doświadczenia z 20-letniego okresu leczenia chorych z przerzutami czerniaka w wątrobie wskazują, że mediana przeżycia chorych operowanych jest 3-krotnie dłuższa w porównaniu z poddawanymi leczeniu systemowemu [26]. Wspomniane obserwacje sugerują, aby częściej wykorzystywać możliwości metod leczenia miejscowego w nowotworach będących dotychczas obszarem zainteresowania onkologii klinicznej.

Standardem postępowania w przypadku nawrotu raka jajnika jest chemioterapia, której rodzaj zależy — przede wszystkim — od kategorii rokowniczej określanej na podstawie czasu od zakończenie pierwotnego leczenia. Wyniki badania przedstawionego podczas tegorocznej konferencji Amerykańskiego Towarzystwa Onkologii Klinicznej (American Society of (linical Oncology; ASCO) wskazują, że u chorych z obecnością mutacji $B R C A$ możliwe jest zastąpienie chemioterapii przez leczenie celowane (olaparib — lek anty-PARP oraz cediranib - lek anty-VEGF). Należy podkreślić, że leczeniu w cytowanym badaniu poddawane były chore na raka jajnika, wrażliwego na związki platyny. Podobnie dla wielu innych omawianych sytuacji oczekiwane jest określenie wartościowych biomarkerów predykcyjnych.

\section{Podsumowanie}

Leczenie systemowe ma coraz większe znaczenie w postępowaniu u chorych na nowotwory. Warunkiem uzyskania wartościowych wyników jest wielospecjalistyczne podejmowanie decyzji terapeutycznych z wykorzystaniem wartościowych czynników predykcyjnych oraz w oparciu o wiarygodne dowody naukowe uzyskane podczas prawidłowo planowanych i prowadzonych badań prospektywnych. Leczenie systemowe powinno uwzględniać również tradycyjne czynniki demograficzno-kliniczne oraz musi być ściśle monitorowane pod względem skuteczności i bezpieczeństwa. Istotna jest również zgodność z zaleceniami postępowania.

Najważniejszym obszarem badań jest obecnie identyfikacja wartościowych czynników predykcyjnych — genetycznych i molekularnych — w ramach wieloośrodkowej współpracy, co ma szczególne znaczenie w przypadku nowotworów o mniejszej częstości występowania. Badania kliniczne powinny być planowane na podstawie wcześniejszego zidentyfikowania biomarkerów, co zmniejszy ryzyko niepowodzeń i nieuzasadnionych kosztów. Opracowanie możliwie pełnego katalogu zaburzeń genetycznych jest niezbędne dla rozwoju leczenia systemowego. Przykładem są wyniki badania, które pozwoliły wstępnie określić,"genetyczną podstawę" (sygnatura genetyczna) uzyskania korzyści w następstwie leczenia anty-CTLA-4 [28].

Szeroko zakrojone i wieloośrodkowe badania translacyjne pomogą z pewnością wyjaśnić wiele nieznanych obszarów onkologii i przyspieszą wdrożenie do klinicznej praktyki nowe metody leczenia ukierunkowanego. Podobne znaczenie powinny mieć badania translacyjne, których celem jest określenie czynników predykcyjnych dla niepożądanych działań związanych z leczeniem. Wspomniane badania powinny być wspierane przez wszystkie zainteresowane podmioty (w tym — środowisko medyczne, instytucje zajmujące się nadzorowaniem systemów funkcjonowania i finansowania ochrony zdrowia i przemysł farmaceutyczny).

\section{Prof. dr hab. n. med. Maciej Krzakowski}

Klinika Nowotworów Płuca i Klatki Piersiowej

Centrum Onkologii — Instytut im. Marii Skłodowskiej-Curie

ul. Roentgena 5, 02-781 Warszawa

e-mail:maciekk@coi.waw.pl

Otrzymano i przyjęto do druku: 22 grudnia 2014 r.

\section{Piśmiennictwo}

1. Garraway LA, Lander ES. Lessons from the cancer genome. Cell 2013; 153: 17-37.

2. Stratton MR. Journeys into the genome of cancer cells. EMBO Mol Med 2013; 5: 169-172.

3. Slamon DJ, Leyland-Jones B, Shak Si wsp. Use of chemotherapy plus a monoclonal antibody against HER2 for metastatic breast cancer that overexpress HER2. N Engl J Med 2001; 344: 783-792.

4. Ellis MJ, Ding L, Shen D i wsp. Whole-genome analysis informs breast cancer response to aromatase inhibition. Nature 2012; 486: 353-360.

5. Lindeman NI, Cagle PT, Beasley MB i wsp. Molecular testing guideline for selection of lung cancer patients for EGFR and ALK tyrosine kinase inhibitors: guideline from the College of American Pathologists, International Association for the Study of Lung Cancer, and Association for Molecular Pathology. J Mol Diagn 2013; 15: 415-453.

6. Lee CK, Brown C, Gralla RJ i wsp. Impact of EGFR inhibitor in non-smal cell lung cancer on progression-free and overall survival: a meta-analysis. J Nat/ Cancer Inst 2013; 105: 595-605. 
7. Prenen $\mathrm{H}$, Vecchione L, Van Cutsem E. Role of targeted agents in metastatic colorectal cancer. Target Oncol 2013; 8: 83-96.

8. Van Krieken JH, Siebers AG, Normanno N. Quality assurances for molecular pathology group - European consensus conference for external quality assessment in molecular pathology. Ann Oncol 2013; 24: 1958-1963.

9. Burrell RA, McGranahan N, Bartek J i wsp. The causes and consequences of genetic heterogeneity in cancer evolution. Nature 2013; 501: 338-345.

10. Swanton C. Cancer evolution: the final frontier of precision medicine? Ann Oncol 2014; 25: 549-551.

11. Miettinen M, Lasota J. Gastrointestinal stromal tumors: review on morphology, molecular pathology, prognosis, and differentia diagnosis. Arch Pathol Lab Med 2006; 130: 1466-1478.

12. Heinrich MC, Owzar CL, Corles CL i wsp. Correlation of kinase genotype and clinical outcome in the North American Intergroup Phase III Trial of imatinib mesylate for treatment of advanced gastrointestinal stromal tumors: CALB 150105 Study by Cancer and Leukemia Group B and Southwest Oncology Group. J Clin Oncol 2008; 26: 5360-5367.

13. Yang JC-H, Sequist LV, Schuler M i wsp. Overall survival in patients with advanced NSCLC harboring common (Del19/L858R) EGFR mutations: analysis of two large, open-label phase III studies of afatinib vs chemotherapy. J Clin Oncol 2014; 32 (supl 5): a8004.

14. Spigel DR, Ervin TJ, Ramlau R i wsp. Randomized phase II trial of onartuzumab in combination with erlotinib in patients with advanced non-small-cell lung cancer. J Clin Oncol 2013; 31: 4105-4114.

15. Weber J. Overcoming immunologic tolerance to melanoma: targeting CTLA-4 with ipilimumab. Oncologist 2008; 13 (supl 4): 16-25.

16. Robert $C$, Thomas $L$, Bondarenko I i wsp. Ipilimumab plus dacarbazine for previously untreated metastatic melanoma. N Engl J Med 2011; 364: 2517-2526.

17. Hodi FS, O'Day SJ, McDermott DF i wsp. Improved survival with ipilimumab in patients with metastatic melanoma. N Engl J Med 2010; 363: 711-723.

18. Hamid O, Robert C, Daud A i wsp. Safety and tumor responses with lambrolizumab (anti-PD-1) in melanoma. NEng/ J Med 2013; 369: 134-144.
19. Wolchok JD, Kluger H, Callahan MK i wsp. Nivolumab plus ipilimumab in advanced melanoma. NEng/ J Med 2013; 369: 122-133.

20. Verma S, Miles D, Gianni Li wsp. Trastuzumab emtansine for HER2-positive advanced breast cancer. N Engl J Med 2012; 367: 1783-1791.

21. Andre F, O'Regan R, Ozguroglu M i wsp. Everolimus for women with trastuzumab-resistant, HER2-positive, advanced brest cancer (BOLERO-3): a randomised, double-blind, placebo controlled phase 3 trial. Lancet Oncol 2014; 15: 580-591.

22. Swain SM, Kim SB, Cortes J i wsp. Pertuzumab, trastuzumab, and docetaxel for HER2-positive metastatic breast cancer (CLEOPATRA study): overall survival results from a randomised, double-blind, palcebo-controlled, phase 3 study. Lancet Oncol 2013; 14: 461-471.

23. Paz-Ares LG, de Marins F, Dediu M i wsp. PARAMOUNT: Final overal survival results of the phase III study of maintenance pemetrexed versus placebo immediately after induction treatment with pemetrexed plus cisplatin for advanced nonsquamous non-small-cell lung camcer. J Clin Oncol 2013; 31: 2895-2902.

24. Gligorov J, Doval D, Bines J i wsp. Maintenance capecitabine and bevacizumab versus bevacizumab alone after initial first-line bevacizumab and docetaxel for patients with HER2-negative metastatic breast cancer (IMELDA): a randomised, open-label, phase 3 trial. Lancet Oncol 2014; 15: 1351-1360.

25. Le Cesne A, Blay J, Ryckewaert T i wsp. Benefit of maintenance therapy with trabectidin beyond the 6 first cycles: results of a prospective, randomized phase II trial. Ann Oncol 2014; 25 (supl 4): a14140.

26. Faries MB, Leung A, Morton DL i wsp. A 20-year experience of hepatic resection for melanoma: is there an expanding role? J Am Coll Surg 2014; 219: 62-68.

27. Liu J, Barry T, Birrer MJ i wsp. A randomized phase 2 trial comparing efficacy of the combination of the PARP inhibitor olaparib and the antiangiogenic cediranib against olaparib alone in recurrent platinum-sensitive ovarian cancer. J Clin Oncol 2014; 32 (supl 5): LBA5500.

28. Snyder A, Makarov V, Merghoub T i wsp. Genetic basis for clinical response to CTLA-4 blockade in melanoma. N Engl J Med 2014; 371: 2189-2199. 